\title{
PENGARUH PELATIHAN DAN PEMBERIAN INSENTIF TERHADAP KINERJA TENAGA MEDIS
}

\author{
Suwandi ${ }^{1)}$ Anggalia Wibasuri, ${ }^{2)}$, Betty Magdalena ${ }^{3)}$ \\ ${ }^{1,2,3)}$ Fakultas Ekonomi dan Bisnis, Institut informatika dan Bisnis Darmajaya \\ Email: ${ }^{1)}$ suwandi.@darmajaya.ac.id, ${ }^{2)}$ anggalia.wibasuri@darmajaya.ac.id. \\ ${ }^{3)}$ bettymagdalena@darmajaya.ac.id
}

\begin{abstract}
Abstrak
Penelitian ini dilakukan di Rumah Sakit Ibu dan Anak Bunda Asy-Syifa. Penelitian ini dilakukan karena terdapat penurunan kinerja tenaga medis, oleh karena itu penelitian ini bertujuan untuk mengetahui apakah penurunan kinerja di sebabkan oleh kurangnya pelatihan dan pemberian insentif terhadap karyawan di rumah sakit ibu dan anak Bunda Asy-Syifa. Jenis penelitian yang digunakan dalam penelitian ini adalah jenis penelitian kuantitatif dengan metode asosiatif yaitu menggunakan analisis regresi linier berganda. Populasi penelitian ini sebanyak 55 orang dengan jumlah sampel penelitian yang sama dengan populasi yaitu sebanyak 55 orang yang diambil dengan teknik pengambilan sampel jenuh. Metode pengumpulan data menggunakan kuesioner yang sebelumnya telah di uji validitas dan reliabilitasnya. Hasil dari penelitian ini menemukan bahwa terdapat Pengaruh signifikan antara pelatihan terhadap kinerja karyawan pada tenaga medis, terdapat pengaruh signifikan antara Pemberian Insentif Terhadap Kinerja Karyawan Pada Tenaga Medis, terdapat pengaruh secara silmultan antara pelatihan dan pemberian insentif terhadap kinerja tenaga medis rumah Sakit Ibu Dan Anak Bunda Asy-Syifa.
\end{abstract}

Kata Kunci : Kinerja, pelatihan, pemberian insentif

\section{PENDAHULUAN}

Perkembangan ilmu pengetahuan dan teknologi yang sangat cepat membawa dampak positif terhadap arti pentingnya manajemen sumber daya manusia dalam melaksanakan aktivitas perusahaan sehingga karyawan dapat bekerja sesuai dengan yang diharapkan oleh perusahaan. Tercapainya tujuan perusahaan tidak hanya tergantung pada peralatan modern, sarana, dan prasarana yang lengkap, tetapi lebih tergantung pada manusia yang melaksanakan pekerjaan. Keberhasilan organisasi sangat dipengaruhi oleh kinerja individu karyawan. Setiap organisasi maupun perusahaan selalu berusaha untuk meningkatkan kinerja karyawan dengan harapan tujuan perusahaan tercapai. Dalam meningkatkan kinerja karyawan, perusahaan 
ISSN Cetak : :2087-0434

E-ISSN : :2599-0810

menempuh beberapa cara yaitu melalui pelatihan, serta memotivasi seperti pemberian insentif langsung kepada karyawan yang memiliki kinerja yang baik.

Melalui proses-proses tersebut, karyawan diharapkan lebih memaksimalkan tanggung jawab atas pekerjaan mereka karena karyawan telah dibekali dengan pelatihan yang tentu berkaitan dengan implementasi kerja mereka. Sedangkan pemberian insentif pada dasarnya adalah hak karyawan dan merupakan kewajiban perusahaan untuk mendukung kontribusi para karyawannya dalam rangka mencapai tujuan yang telah ditentukan. Kinerja merupakan gambaran mengenai tingkat pencapaian pelaksanaan tugas suatu organisasi, dalam upaya mewujudkan sasaran, tujuan, misi dan visi organisasi (Bastian, 2001).

Rumah Sakit Ibu Dan Anak Bunda Asy-Syifa merupakan sebuah perusahaan yang bergerak dibidang jasa. Rumah sakit ibu dan anak ini hanya melayani pasien perempuan atau ibu-ibu yang sedang hamil dan anak-anak. Rumah Sakit Ibu dan Anak Bunda Asy-Syifa hadir sejak 9 maret 2013. Dari hasil observasi pendahuluan yang dilakukan diketahui bahwa jumlah kunjungan bayi / anak, peserta KB, dan persalinan sebesar 23,668 tidak mencapai target dari RSIA Bunda Asy-Syifa. Pada tahun 2016 dan 2017 jumlah kunjungan mengalami kenaikan sebesar 32,188 dan 33,39 telah mencapai target dari RSIA Bunda Asy-Syifa. Di tahun 2018 total kunjungan mengalami penurunan sebesar 28,380 tidak mencapai target RSIA Bunda Asy-Syifa.

Manajemen RSIA Bunda Asy-Syifa menilai ada faktor penurunan pada kinerja karyawan dikarenakan pelayanan kekonsumen kurang memberikan hasil yang baik. Kinerja yang diterapkan oleh karyawan pada tenaga medis di Rumah Sakit Ibu dan Anak Bunda Asy-Syifa kurang memberikan hasil yang baik, Hal ini dapat dilihat dari fenomena yang muncul mengenai permasalahan yang ada di RSIA Bunda Asy-Syifa yang diperoleh berdasarkan hasil wawancara dengan Bapak Zulharbi selaku staff personalia, masalah tersebut seperti rendahnya otonomi tenaga medis terlihat dimana ia selalu bertanya kepada dokter ataupun tenaga medis yang sudah bekerja lama di RSIA Bunda Asy-Syifa mengenai tugasnya padahal semestinya ia memiliki kesempatan untuk dapat merubah dan mengambil keputusan sendiri dalam hal melayani pasien sesuai kebutuhan pasien berdasarkan standar operasional pekerjaannya yang juga merupakan batasan otonomi seorang tenaga 
ISSN Cetak : :2087-0434

E-ISSN : :2599-0810

medis yaitu standar pengkajian, standar diagnose keperawatan, standar perencanaan, standar pelaksanaan, standar evaluasi. Hal ini memberi dampak terhadap kinerjanya, karena karyawan pada tenaga medis terlihat kurang mampu dan kurang percaya diri terhadap kemampuan tugasnya.

Kinerja karyawan pada tenaga medis juga dapat dilihat dari bagaimana karyawan pada tenaga medis menerapkan prosedur dasar rumah sakit. Tugas karyawan pada tenaga medis yaitu meliputi penerimaan pasien,mempersiapkan pasien yang akan pulang, melakukan rujukan, dan menggunakan alat medic dan keperawatan sesuai standar rumah sakit. Menurut hasil wawancara kepada kepala tenaga medis dan keluarga pasien masih ada karyawan pada tenaga medis yang tidak melakukan hal-hal tersebut, seperti saat mempersiapkan pasien yang akan pulang. Seharusnya karyawan pada tenaga medis menjelaskan kepada pasien dan keluarga pasien tentang perawatan dirumah, tetapi terkadang ada karyawan pada tenaga medis yang tidak menjelaskan secara detail dengan pasien maupun keluarga pasien tentang hal tersebut.

Dalam meningkatkan kinerja karyawan pada tenaga medis bisa dilihat dari faktor - faktor yang mempengaruhi kinerja,salah satu hal yang perlu ditingkatkan adalah pelatihan dan pemberian insentif. Selama ini RSIA Bunda Asy-Syifa hanya menerima karyawan yang sudah mempunyai keahlian, walaupun RSIA Bunda AsySyifa hanya menerima karyawan yang sudah mempunyai keahlian, tetapi RSIA Bunda Asy-Syifa juga mengadakan program pelatihan didalam supaya karyawan tersebut menambah pengetahuan dan meningkatkan keahliannya.

Selanjutnya, perusahaan diwajibkan untuk berupaya menciptakan kondisi yang bagus agar karyawan pada tenaga medis dapat bergairah atau bersemangat dalam melakukan pekerjaannya, salah satunya adalah dengan memberikan insentif. Tujuan insentif pada hakekatnya adalah untuk meningkatkan motivasi karyawan pada tenaga medis dalam upaya mencapai tujuan-tujuan organisasi dalam menawarkan keuangan yang melebihi upah dan gaji dasar. Oleh karena itu, ruang lingkup dalam penelitian ini adalah menguji pengaruh pelatihan dan pemberian insentif terhadap kinerja karyawan pada tenaga medis di RSIA Bunda Asy-Syifa 
ISSN Cetak : 2087-0434

E-ISSN : :2599-0810

Pelatihan merupakan serangkaian aktivitas individu dalam meningkatkan keahlian dan pengetahuan secara sistematis sehingga mampu memiliki kinerja yang professional di bidangnya (Widodo, 2015). Pelatihan adalah proses pembelajaran yang memungkinkan pegawai melaksanakan pekerjaan yang sekarang sesuai dengan standar. Menurut Dessler (2010), pelatihan adalah proses mengajar keterampilan yang dibutuhkan karyawan baru untuk melakukan pekerjaannya. Idealnya, pelatihan harus dirancang untuk mewujudkan tujuan-tujuan organisasi, yang pada waktu bersamaan juga mewujudkan tujuan-tujuan para pekerja secara perorangan.

Pelatihan merupakan salah satu usaha dalam meningkatkan mutu sumber daya manusia dalam organisasi, baik yang baru ataupun yang sudah bekerja perlu mengikuti pelatihan karena adanya tuntutan pekerjaan yang dapat berubah akibat perubahan lingkungan kerja, strategi, dan lainnya. Dari definisi diatas dapat disimpulkan bahwa pelatihan bukanlah tujuan, melainkan suatu alat dari manajemen untuk mencapai tujuan perusahaan yang mana merupakan usaha dan tanggung jawab pimpinan terhadap karyawan yang menjadi tanggung jawabnya. Dengan adanya pelatihan akan dapat menimbulkan perubahan dalam kebiasaan bekerja, perubahan sikap, tingkah laku, keterampilan serta pengetahuan karyawan.

Setiap pelatihan yang akan diadakan harus selalu memperhatikan sejauh mana pola pelatihan yang dilaksanakan dapat menjamin proses belajar yang efektif. Jenis-jenis pelatihan yang biasa dilakukan dalam suatu organisasi atau perusahaan (Widodo, 2015). Antara lain; 1) pelatihan dalam kerja (on the job training) 2) Magang, 3) Pelatihan diluar kerja (of the job training), 4) Pelatihan ditempat mirip sesungguhnya dan 5) Simulasi kerja (job simulation).

Tujuan diadakannya pelatihan yang diselenggarakan perusahaan terhadap karyawan dikarenakan perusahaan menginginkan adanya perubahan dalam kinerja karyawan sehingga dapat sesuai dengan tujuan perusahaan. Tujuan pelatihan (Hasibuan, 2010). Sebagai berikut; 1). Produktivitas kerja. Dengan pelatihan, produktivitas kerja karyawan akan meningkat, kualitas dan kuantitas semakin baik, 2). Efisiensi. Pelatihan karyawan yang bertujuan untuk meningkatkan efisiensi tenaga, waktu, bahan baku, dan mengurangi hausnya mesin-mesin. 3). Kerusakan. Pelatihan karyawan bertujuan untuk mengurangi kerusakan barang, produksi, dan mesin-mesin. 4). Kecelakaaan Pelatihan bertujuan untuk mengurangi tingkat 
ISSN Cetak : :2087-0434

E-ISSN : :2599-0810

kecelakaan karyawan, sehingga jumlah biaya pengobatan yang dikeluarkan perusahaan berkurang. 5). Pelayanan. Pelatihan bertujuan untuk meningkatkan pelayanan yang lebih baik dari karyawan kepada customer, 6). Moral. Dengan pelatihan, moral karyawan akan lebih baik karena keahlian dan keterampilannya sesuai dengan pekerjaannya sehingga mereka antusias untuk menyelesaikan pekerjaannya. 7). Karier. Dengan pelatihan, kesempatan untuk meningkatkan karier karyawan semakin besar, karena keahlian, keterampilan, dan potensi kerjanya lebih baik. 8). Balas jasa. Dengan pelatihan, balas jasa seperti gaji, upah, insentif akan meningkat karena prestasi kerja semakin besar. 9). Konsumen. Pelatihan karyawan akan memberikan kemampuan lebih dalam melayani konsumen.

Dalam kamus besar bahasa Indonesia disebutkan bahwa insentif adalah tambahan penghasilan (uang,barang, dan lain sebagainya) yang diberikan sebagai perangsang gairah kerja. Insentif adalah imbalan langsung yang dibayarkan kepada karyawan karena kinerjanya melebihi standar yang ditentukan (Rivai, 2013). Insentif merupakan tambahan balas jasa yang diberikan kepada karyawan tertentu yang prestasinya diatas prestasi standar (Hasibuan, 2012). Insentif merupakan pemberian uang diluar gaji yang dilakukan oleh pemimpin organisasi sebagai pengakuan terhadap prestasi kerja dan kontribusi karyawan pada organisasi (Mangkunegara, 2011). Berdasarkan pendapat di atas, dapat disimpulkan bahwa insentif merupakan salah satu bentuk rangsangan atau motivasi yang diberikan kepada karyawan untuk mendorong semangat kerja karyawan agar mereka dapat meningkatkan kinerjanya dalam mencapai tujuan organisasi.

Jenis-jenis insentif dalam suatu perusahaan harus dituangkan secara jelas sehingga dapat diketahui oleh pegawai dan oleh perusahaan tersebut dan dapat dijadikan kontribusi yang baik untuk dapat menambah gairah kerja bagi karyawan yang bersangkutan. Jenis-jenis insentif (Siagian, 2012). Antara lain; 1) Piece Work. Merupakan teknik yang digunakan untuk mendorong kinerja pegawai berdasarkan hasil pekerjaan pegawai yang dinyatakan dalam jumlah unit produksi. 2) Bonus. Merupakan insentif yang diberikan kepada pegawai yang mampu bekerja sedemikian rupa tingkat produksi yang baku.3) Komisi. Merupakan bonus yang diterima karena berhasil melaksanakan tugas dan sering diterapkan oleh tenagatenaga penjualan. 4) Insentif Bagi Eksekutif. Merupakan insentif yang diberikan 
ISSN Cetak : :2087-0434

E-ISSN : :2599-0810

kepada pegawai khususnya manajer atau pegawai yang memiliki kedudukan tinggi dalam suatu hal, 5) Kurva Kematangan. Merupakan insentif yang diberikan kepada tenaga kerja yang karena masa kerja dan golongan pangkat serta gaji yang tidak bisa mencapai pangkat dan penghasilan yang lebih tinggi lagi, 6) Rencana Insentif Kelompok. Merupakan kenyataan bahwa dalam banyak organisasi, kinerja bukan karena keberhasilan individual melainkan karena keberhasilan kelompok kerja yang mampu bekerja sebagai suatu tim.

Tujuan utama dari insentif adalah untuk memberikan tanggung jawab dan dorongan kepada karyawan dalam rangka meningkatkan kualitas dan kuantitas hasil kerjanya (Rivai, 2013). Dengan demikian, insentif akan sangat mempengaruhi motivasi seseorang dalam bekerja. Selain tujuan,pemberian insentif kepada karyawan bermanfaat untuk memberikan tanggung jawab dan dorongan kepada karyawan untuk dapat meningkatkan produktivitas kerja.

Salah satu alasan pentingnya pemberian insentif karena adanya ketidak sesuaian kompensasi yang dibayarkan kepada eksekutif dengan pekerja lain (Rivai, 2011). Program insentif adalah salah satu cara untuk memungkinkan seluruh pekerja merasakan bersama kemakmuran perusahaan. Selain itu, ada kesadaran yang tumbuh bahwa program pembayaran tradisional seringkali tidak bagus dalam menghubungkan pembayaran dengan kinerja jika organisasi ingin mencapai inisiatif strategis mereka, maka pembayaran perlu dihubungkan dengan kinerja sedemikian rupa sehingga pembayaran itu mengikuti tujuan karyawan dan tujuan organisasi.

Insentif bisa berwujud bonus tahunan, insentif langsung, insentif individu, insentif tim, pembagian keuntungan dan bagi hasil. Sedangkan, menurut dessler dalam bukunya yang berjudul manajemen sumber daya manusia jilid 1 bahwa insentif dibagi menjadi beberapa indikator yaitu binus, tunjangan kesehatan, promosi jabatan, fasilitas kesejahteraan sosial dan cuti.

Kinerja karyawan merupakan suatu hal penting dalam upaya perusahaan untuk mencapai tujuannya. Kinerja berasal dari pengertian performance, ada pula yang memberikan pengertian performance sebagai hasil kerja atau prestasi kerja. Namun, sebenarnya kinerja mempunyai makna yang lebih luas, bukan hanya hasil kerja, tetapi termasuk bagaimana proses pekerjaan berlangsung (Wibowo,2011). Kinerja merupakan gambaran mengenai tingkat pencapaian pelaksanaan suatu 
ISSN Cetak : :2087-0434

E-ISSN : :2599-0810

program kegiatan atau kebijakan dalam mewujudkan sasaran, tujuan, visi, dan misi organisasi yang dituangkan melalui perencanaan strategis suatu organisasi (Moeheriono, 2012). Kinerja dapat diketahui dan diukur jika individu atau sekelompok karyawan telah mempunyai kriteria atau standar keberhasilan tolak ukur yang ditetapkan organisasi. Peningkatan kinerja karyawan akan membawa kemajuan bagi perusahaan untuk dapat bertahan dalam suatu persaingan lingkungan bisnis yang tidak stabil. Oleh karena itu, upaya-upaya untuk meningkatkan kinerja karyawan merupakan tantangan manajemen yang paling serius karena keberhasilan untuk mencapai tujuan dan kelangsungan hidup perusahaan tergantung pada kualitas kinerja sumber daya manusia yang ada didalamnya.

Beberapa metode penilaian kinerja karyawan yang dapat diterapkan (Moeheriono, 2012). Antara lain; 1) Metode Skala Peringkat. System ini terdiri atas dua bagian yaitu: pertama, bagian suatu daftar karakteristik dan kedua, bidang ataupun prilaku yang akan dinilai dan bagian skala. Kekuatan system ini adalah dapat diselesaikan dengan cepat dan dengan upaya sesering mungkin. Kelemahan dari system ini adalah subjektif karena kriteria penilaian yang digunakan amat samar dan kurang tepat, khususnya pada skala yang digunakan, 2) Metode Daftar Pertanyaan (Checklist). Hasil metode ini adalah bobot nilai pada lembar checklist, tetapi checklist dapat dijadikan sebagai gambaran hasil kerja karyawan yang akurat. Keuntungannya adalah biaya yang murah, pengurusannya mudah, penilai hanya membutuhkan waktu pelatihan yang sederhana dan distandarisasi. Kelemahannya terletak pada penyimpangan penilai yang lebih mengedepankan kriteria pribadi karyawan dalam menentukan kriteria hasil kerja, kesalahan menafsir materi-materi checklist, dan penentuan bobot nilai tidak seharusnya dilakukan oleh departemen sumber daya manusia. 3) Metode Pilihan Terarah (Forced Choice Method). System ini menggunakan evaluasi dalam lima skala yaitu, berkinerja sangat tinggi, berkinerja rata-rata tinggi, berkinerja rata-rata, berkinerja rata-rata rendah dan berkinerja sangat rendah. Kekuatan system ini adalah dapat mengidentifikasi karyawan yang memiliki prestasi tinggi dan luar biasa serta dapat mengurangi penyimpangan penilaian. Kelemahannya adalah tidak realistis mendorong pimpinan yang memiliki hanya empat atau lima karyawan untuk mendistribusikannya ke lima level. 4) Metode Peristiwa Kritis (Critical Incident Method). Pada system ini dilaksanakan dengan 
ISSN Cetak : :2087-0434

E-ISSN : :2599-0810

membuat catatan-catatan contoh yang luar biasa baik atau tidak diinginkan dari perilaku yang berhubungan dengan kerja seorang karyawan dan meninjaunya bersama karyawan lain pada waktu yang telah ditentukan sebelumnya. Keuntungan metode ini adalah menyajikan fakta-fakta keras yang spesifik untuk menjelaskan evaluasi dan memastikan bahwa pimpinan berfikir tentang evaluasi, serta mengidentifikasikan contoh-contoh khusus tentang kinerja yang baik dan jelek dan merencanakan perbaikan terhadap kemerosotan. Kelemahannya adalah sulit untuk menilai atau memeringkatkan karyawan yang berhubungan dengan satu sama lain.

Banyak indikator yang mempengaruhi kinerja seorang karyawan, indikatorindikator penilaian kinerja (Mangkunegara, 2011). Antara lain; 1) Kualitas. Kualitas kerja adalah seberapa baik seorang karyawan mengerjakan apa yang seharusnya dikerjakan. 2) Kuantitas. Kuantitas kerja adalah seberapa lama seorang pegawai bekerja dalam satu harinya. Kuantitas kerja ini dapat dilihat kecepatan kerja setiap pegawai itu masing-masing masing 3) Pelaksanaan tugas. Pelaksanaan tugas adalah seberapa jauh karyawan mampu melakukan pekerjaannya dengan akurat atau tidak ada kesalahan. 4) Tanggung jawab. Tanggung jawab terhadap pekerjaan adalah kesadaran akan kewajiban karyawan untuk melaksanakan pekerjaan yang diberikan perusahaan.

Penelitian terdahulu dijadikan salah satu bahan acuan dan pendukung untuk melakukan penelitian. Penelitian sebelumnya telah mengkaji tentang variabel yang akan diteliti oleh peneliti. Peneliti menggunakkan penelitian terdahulu untuk digunakan sebagaiacuan dan bahan penelitian. Beberapa penelitian yang telah dilakukan sebelumnya yaitu Dimas (2015) dengan hasil penelitian yang menunjukan pemberian insentif mempunyai hubungan positif dan pengaruh signifikan terhadap kinerja karyawan. Mitriadi saputra (2016) dengan hasil penelitian menunjukan bahwa kinerja para tenaga medis puskesmas kecamatan Kampar Utara belum maksimal karena masih terdapat kekurangan dan tidak berjalan sesuai dengan standar operasional prosedur (SOP) yang telah di tetapkan

Dari latar belakang dan kerangka teori yang sudah dipaparkan maka dirumuskan hipotesis Terdapat pengaruh pelatihan dan pemberian insentif terhadap kinerja karyawan pada tenaga medis di Rumah Sakit Ibu dan Anak Bunda Asy-Syifa 
ISSN Cetak : :2087-0434

E-ISSN $\quad: 2599-0810$

\section{METODE PENELITIAN}

Penelitian ini merupakan penelitian asosiatif atau hubungan. Menurut V.Wiratna Sujarweni (2018) penelitian ini bertujuan untuk mengetahui hubungan antara dua variabel atau lebih serta mengetahui pengaruhnya. Dengan penelitian ini maka akan dapat dibangun suatu teori yang dapat berfungsi untuk menjelaskan, meramalkan dan mengontrol suatu gejala

Metode penelitian berisikan jenis penelitian, waktu dan tempat penelitian, subjek penelitian, prosedur, data dan instrumen, teknik pengumpulan data, teknik analisis data, populasi dan sampel, serta hal-hal lain yang berkaitan dengan cara penelitiannya. Dalam metode analisis data tidak perlu dituliskan secara detail namun kegunaan dari metode analisis data dalam kaitannya dengan tujuan artikel perlu dipaparkan. Data primer adalah data yang diperoleh dari responden melalui kuesioner, kelompok focus, dan panel, atau juga data hasil wawancara peneliti dengan narasumber. Sebagai data primer dalam penelitian ini adalah hasil kuesioner yang dibagikan oleh penulis kepada karyawan tenaga medis di RSIA Bunda AsySyifa. Data sekunder merupakan data yang didapat dari catatan, buku, majalah berupa laporan keuangan publikasi perusahaan, laporan pemerintah, artikel, bukubuku sebagai teori, majalah, dan lain sebagainya. Sebagai data sekunder dalam penelitian ini adalah data berkaitan dengan RSIA Bunda Asy-Syifa yang meliputi sejarah berdirinya perusahaan dan jumlah karyawan

Metode pengumpulan data menggunakan wawancara dan kuesioner. Wawancara dilakukan dengan karyawan divisi pelaksana bidang umum dan SDM dan kuesioner yang dibagikan kepada karyawan tenaga medis di RSIA Bunda AsySyifa.

Populasi dalam penelitian ini sebanyak 55 karyawan pada tenaga medis di RSIA Bunda Asy-Syifa. Teknik sampling penelitian ini adalah non probability sampling dengan menggunakan sampling jenuh. Sampling jenuh adalah teknik penentuan sampel bila semua anggota populasi digunakan sebagai sampel. Selain itu, dilakukan juga uji asumsi klasik menggunakan uji normalitas yang digunakan untuk menguji apakah distribusi variabel terkait untuk setiap variabel bebas tertentu berdistribusi normal atau tidak dalam model regresi linear, asumsi ini ditunjukkan oleh nilai eror yang berdistribusi normal. Uji liniearitas yang bertujuan untuk 
ISSN Cetak : :2087-0434

E-ISSN $\quad: 2599-0810$

mengetahui apakah dua variabel mempunyai hubungan yang linear atau tidak secara signifikan, sedangkan uji multikolinearitas bertujuan untuk menguji apakah model regresi ditemukan adanya korelasi antara variabel bebas atau tidak. Setelah data memenuhi asumsi klasik maka dilanjutkan dengan analisis data

Metode analisis data yang digunakan dalam penelitian ini adalah regresi linear berganda. Regresi tersebut dilakukan dengan tujuan untuk mengetahui arah pengaruh variabel bebas terhadap variabel terikat, apakah pengaruhnya positif atau negatif. Selain itu juga di gunakan Uji t digunakan untuk mengetahui seberapa jauh pengaruh masing - masing independen terhadap dependen atau pengaruh masing masing variabelnya dan Uji F dikenal dengan uji serentak atau uji model / uji Anova, yaitu uji yang digunakan untuk melihat bagaimanakah pengaruh semua variable bebas secara bersama-sama terhadap variable teikat. Atau untuk menguji apakah model regresi yang kita buat baik / signifikan atau tidak baik / non signifikan.

\section{HASIL DAN PEMBAHASAN}

Karakteristik responden dalam penelitian ini berjumlah 55 orang. Berdasarkan pendidikan diketahui bahwa jumlah tertinggi yaitu Strata 1 (S1), artinya karyawan pada tenaga medis yang menjadi responden didominasi oleh Strata 1 (S1) yaitu sebanyak 46 orang dan pendidikan Strata 2 (S2) sebanyak 9 orang. Karakteristik responden lama bekerja diketahui bahwa jumlah tertinggi yaitu lama bekerja 1 - 3 Tahun, artinya karyawan pada tenaga medis yang bekerja di RSIA Bunda Asy-Syifa didominasi oleh lama bekerja 1 - 3 Tahun dengan jumah 26 dengan persentase $47,3 \%$.

Hasil rekapitulasi jawaban responden dalam kuesioner disajikan dalam tabel di bawah ini: 


$\begin{array}{ll}\text { ISSN Cetak } & : 2087-0434 \\ \text { E-ISSN } & : 2599-0810\end{array}$

Tabel 1

Rekapitulasi Jawaban Kuesioner Variabel Pelatihan (X1)

\begin{tabular}{|c|c|c|c|c|c|c|c|c|c|c|c|}
\hline \multirow{3}{*}{ No } & \multirow{3}{*}{ Daftar Pernyataan } & \multicolumn{10}{|c|}{ Jawaban } \\
\hline & & \multicolumn{2}{|c|}{ SS (5) } & \multicolumn{2}{|c|}{$\mathbf{S ( 4 )}$} & \multicolumn{2}{|c|}{ CS(3) } & \multicolumn{2}{|c|}{$\mathbf{T S}(2)$} & \multicolumn{2}{|c|}{ STS(1) } \\
\hline & & $\mathbf{F}$ & $\%$ & $\mathbf{F}$ & $\%$ & $\mathbf{F}$ & $\%$ & $\mathbf{F}$ & $\%$ & $\mathbf{F}$ & $\%$ \\
\hline 1 & $\begin{array}{l}\text { Pelatih menguasai materi pelatihan } \\
\text { yang disampaikan kepada peserta } \\
\text { pelatihan }\end{array}$ & 31 & 56,4 & 23 & 41,8 & 1 & 1,8 & 0 & 0,0 & 0 & 0,0 \\
\hline 2 & $\begin{array}{l}\text { Pelatih ahli dalam menyampaikan } \\
\text { materi saat pelatihan }\end{array}$ & 3 & 5,5 & 40 & 72,7 & 9 & 16,4 & 3 & 5,5 & 0 & 0,0 \\
\hline 3 & $\begin{array}{l}\text { Peserta pelatihan dipilih melalui } \\
\text { seleksi yang objektif oleh perusahaan }\end{array}$ & 33 & 60,0 & 21 & 38,2 & 0 & 0,0 & 1 & 1,8 & 0 & 0,0 \\
\hline 4 & $\begin{array}{l}\text { Peserta selalu bersemangat untuk } \\
\text { mengikuti pelatihan }\end{array}$ & 34 & 61,8 & 21 & 38,2 & 0 & 0,0 & 0 & 0,0 & 0 & 0,0 \\
\hline 5 & $\begin{array}{l}\text { Materi yang disampaikan } \\
\begin{array}{l}\text { menambah } \\
\text { pelatihan }\end{array}\end{array}$ & 33 & 60,0 & 20 & 36,4 & 2 & 3,6 & 0 & 0,0 & 0 & 0,0 \\
\hline 6 & $\begin{array}{l}\text { Materi yang disampaikan dalam } \\
\text { pelatihan sesuai dengan tujuan yang } \\
\text { ingin dicapai oleh perusahaan }\end{array}$ & 10 & 18,2 & 39 & 70,9 & 6 & 10,9 & 0 & 0,0 & 0 & 0,0 \\
\hline
\end{tabular}

Tabel 2

Rekapitulasi Jawaban Kuesioner Variabel Pemberian Insentif (X2)

\begin{tabular}{|c|c|c|c|c|c|c|c|c|c|c|c|}
\hline \multirow{3}{*}{ No } & \multirow{3}{*}{ Daftar Pernyataan } & \multicolumn{10}{|c|}{ Jawaban } \\
\hline & & \multicolumn{2}{|c|}{ SS (5) } & \multicolumn{2}{|c|}{$\mathbf{S ( 4 )}$} & \multicolumn{2}{|c|}{$\mathbf{C S}(3)$} & \multicolumn{2}{|c|}{$\mathbf{T S}(2)$} & \multicolumn{2}{|c|}{ STS(1) } \\
\hline & & $\mathbf{F}$ & $\%$ & $\mathbf{F}$ & $\%$ & $\mathbf{F}$ & $\%$ & $\mathbf{F}$ & $\%$ & $\mathbf{F}$ & $\%$ \\
\hline 1 & $\begin{array}{l}\text { Berdasarkan keterampilan karyawan } \\
\text { dalam bekerja, karyawan merasa puas } \\
\text { dengan bonus yang karyawan terima } \\
\text { dari perusahaan }\end{array}$ & 2 & 3,6 & 22 & 40,0 & 28 & 50,9 & 3 & 5,5 & 0 & 0,0 \\
\hline 2 & $\begin{array}{l}\text { Bonus yang karyawan terimabernilai } \\
\text { bagi kehidupan karyawan }\end{array}$ & 8 & 14,5 & 23 & 41,8 & 24 & 43,6 & 0 & 0,0 & 0 & 0,0 \\
\hline 3 & $\begin{array}{lccr}\begin{array}{l}\text { Karyawan } \\
\text { kesehatan }\end{array} & \text { yuas } & \text { dengan } & \text { tunjangan } \\
\text { perusahaan } & & \text { diberikan } & \text { oleh } \\
\end{array}$ & 11 & 20,0 & 15 & 27,3 & 28 & 50,9 & 1 & 1,8 & 0 & 0,0 \\
\hline
\end{tabular}


Junal Ilmiah Ekonomi Manajemen

Vol. 12 No.02, Hal 104-118
ISSN Cetak
: 2087-0434
E-ISSN
: 2599-0810

\begin{tabular}{|c|c|c|c|c|c|c|c|c|c|c|c|}
\hline 4 & $\begin{array}{l}\text { Seluruh karyawan memperoleh } \\
\text { tunjangan kesehatan sesuai ketentuan }\end{array}$ & 5 & 9,1 & 20 & 36,4 & 30 & 54,5 & 0 & 0,0 & 0 & 0,0 \\
\hline 5 & $\begin{array}{l}\text { Promosi jabatan yang diberikan } \\
\text { perusahaan dirasa adil }\end{array}$ & 2 & 3,6 & 21 & 38,2 & 32 & 58,2 & 0 & 0,0 & 0 & 0,0 \\
\hline 6 & $\begin{array}{l}\text { Karyawan memahami kriteria atau } \\
\text { persyaratan dalam promosi jabatan }\end{array}$ & 10 & 18,2 & 23 & 41,8 & 22 & 40,0 & 0 & 0,0 & 0 & 0,0 \\
\hline 7 & $\begin{array}{l}\text { Perushaan memberikan dengan baik } \\
\text { sarana hiburan (rekreasi) }\end{array}$ & 8 & 14,5 & 20 & 36,4 & 27 & 49,1 & 0 & 0,0 & 0 & 0,0 \\
\hline 8 & $\begin{array}{l}\text { Karyawan merasa puas dengan fasilitas } \\
\text { kesejahteraan social yang diberikan } \\
\text { perusahaan kepada karyawan }\end{array}$ & 12 & 21,8 & 15 & 27,3 & 27 & 49,1 & 1 & 1,8 & 0 & 0,0 \\
\hline 9 & $\begin{array}{l}\text { Karyawan memahami ketentuan atau } \\
\text { persyaratan memperoleh cuti }\end{array}$ & 6 & 10,9 & 16 & 29,1 & 31 & 56,4 & 2 & 3,6 & 0 & 0,0 \\
\hline 10 & $\begin{array}{l}\text { Cuti yang karyawan perolehdirasa } \\
\text { bermanfaat sesuai kebutuhan }\end{array}$ & 11 & 20,0 & 17 & 30,9 & 26 & 47,3 & 1 & 1,8 & 0 & 0,0 \\
\hline
\end{tabular}

Tabel 3

Rekapitulasi Jawaban Kuesioner Variabel Kinerja (Y)

\begin{tabular}{|c|c|c|c|c|c|c|c|c|c|c|c|}
\hline \multirow{3}{*}{ No } & \multirow{3}{*}{ Daftar Pernyataan } & \multicolumn{10}{|c|}{ Jawaban } \\
\hline & & \multicolumn{2}{|c|}{ SS (5) } & \multicolumn{2}{|c|}{ S(4 } & \multicolumn{2}{|c|}{$\mathrm{CS}(3)$} & \multicolumn{2}{|c|}{$\mathbf{T S}(2)$} & \multicolumn{2}{|c|}{ STS(1) } \\
\hline & & $\mathbf{F}$ & $\%$ & $\mathbf{F}$ & $\%$ & $\mathbf{F}$ & $\%$ & $\mathbf{F}$ & $\%$ & $\mathbf{F}$ & $\%$ \\
\hline 1 & $\begin{array}{l}\text { Bapak/ibu berupaya menjadi individu } \\
\text { yang selalu berusaha untuk } \\
\text { meningkatkan kualitas } \\
\text { Kinerja }\end{array}$ & 16 & 29,1 & 23 & 41,8 & 16 & 29,1 & 0 & 0,0 & 0 & 0,0 \\
\hline 2 & $\begin{array}{l}\text { Kualitas kerja bapak/ibu lebih baik } \\
\text { dari pegawai lain }\end{array}$ & 13 & 23,6 & 13 & 23,6 & 27 & 49,1 & 2 & 3,6 & 0 & 0,0 \\
\hline 3 & $\begin{array}{l}\text { Kuantitas kerja saya sesuai dengan } \\
\text { standar kerja yang ditentukan }\end{array}$ & 13 & 23,6 & 16 & 29,1 & 26 & 47,3 & 0 & 0,0 & 0 & 0,0 \\
\hline 4 & $\begin{array}{l}\text { Kuantitas atau jumlah kerja yang saya } \\
\text { lakukan dalam satu periode melebihi } \\
\text { karyawan lain }\end{array}$ & 7 & 12,7 & 36 & 65,5 & 12 & 21,8 & 0 & 0,0 & 0 & 0,0 \\
\hline
\end{tabular}




ISSN Cetak $\quad: 2087-0434$

\begin{tabular}{|c|l|l|c|c|c|c|c|c|c|c|c|}
\hline 5 & $\begin{array}{l}\text { Terampil dalam melaksanakan } \\
\text { pekerjaan sesuai dengan tugas dan } \\
\text { fungsi }\end{array}$ & 5 & 9,1 & 24 & 43,6 & 26 & 47,3 & 0 & 0,0 & 0 & 0,0 \\
\hline 6 & $\begin{array}{l}\text { Saya memiliki pengalaman kerja } \\
\text { yang tidak perlu diragukan lagi dalam } \\
\text { melaksanakan tugas }\end{array}$ & 10,2 & 21 & 38,2 & 23 & 41,8 & 1 & 1,8 & 0 & 0,0 \\
7 & $\begin{array}{l}\text { Dalam menyelesaikan tugas saya } \\
\text { dapat menyelesaikan dengan tepat } \\
\text { dan cepat sesuai waktu yang } \\
\text { ditentukan } 12\end{array}$ & 21,8 & 20 & 36,4 & 22 & 40,0 & 1 & 1,8 & 0 & 0,0 \\
8 & $\begin{array}{l}\text { Saya berkomitmen dan bertanggung } \\
\text { jawab atas pekerjaan }\end{array}$ & 13 & 23,6 & 15 & 27,3 & 26 & 47,3 & 1 & 1,8 & 0 & 0,0 \\
\hline
\end{tabular}

Dari analisa data menggunakan regresi linerar berganda didapatkan persamaan sebagai berikut: $Y=\mathbf{5 , 1 5 9}+\mathbf{0 , 5 4 2 X 1}+\mathbf{0 , 3 0 1 X 2}$. Persamaan tersebut dapat diartikan Nilai konstanta a sebesar 5,159 menyatakan bahwa kinerja karyawan pada tenaga medis RSIA Bunda Asy-Syifa sebesar 5,159 apabila pelatihan dan pemberian insentif bernilai $=0$. Koefisien regresi untuk $\mathrm{X} 1=0,542$ menyatakan bahwa setiap penambahan pelatihan sebesar satu satuan maka akan meningkatkan kinerja karyawan tenaga medis pada RSIA Bunda Asy-Syifa. Koefisien regresi untuk X2=0,301 menyatakan bahwa setiap penambahan pemberian insentif sebesar satu satuan maka akan meningkatkan kinerja karyawan tenaga medis pada RSIA Bunda Asy-Syifa sebesar 0,301.

Selain itu, dari anova table didapatkan nilai koefisien korelasi (R) sebesar 0,515 artinya tingkat hubungan antara Pelatihan (X1), Pemberian Insentif (X2) dan Kinerja Karyawan pada tenaga medis (Y) adalah positif kuat. Dari uji t di ketahui Koefisien determinan $\mathrm{R}$ Square $\left(\mathrm{R}^{2}\right)$ sebesar 0,266 artinya bahwa kinerja k aryawan pada tenaga medis (Y) dipengaruhi oleh pelatihan (X1) dan pemberian insentif (X2) sebesar 26,6\%, sedangkan sisanya $0,734 \%$ dipengaruhi oleh factor/variable lain diluar penelitian ini

Pada pengujian hipotesis pada pelatihan (X1) diperoleh nilai sig $(0,013)<$ Alpha $(0,05)$ dengan demikian Ho ditolak dan $\mathrm{H}_{\mathrm{a}}$ diterima, sehingga dapat disimpulkan bahwa pelatihan (X1) secara parsial berpengaruh terhadap kinerja 
ISSN Cetak : :2087-0434

E-ISSN $\quad: 2599-0810$

Karyawan pada tenaga medis (Y). Dengan demikian, jika kita meningkatkan pelatihan akan berdampak meningkatnya kinerja karyawan pada tenaga medis, jadi semakin meningkatnya pelatihan akan semakin meningkatnya kinerja karyawan pada tenaga medis begitupun sebaliknya.

Pada variabel X2, pemberian insentif (X2) diperoleh nilai sig $(0,010)<$ Alpha $(0,05)$ dengan demikian Ho ditolak dan $\mathrm{H}_{\mathrm{a}}$ diterima, sehingga dapat disimpulkan bahwa pemberian insentif (X2) secara parsial berpengaruh terhadap kinerja karyawan pada tenaga medis (Y). Dengan demikian, jika kita meningkatkan pemberian insentif (X2) akan berdampak meningkatnya kinerja karyawan pada tenaga medis (Y), semakin meningkatnya pemberian insentif akan meningkatkan kinerja karyawan pada tenaga medis begitupun sebaliknya.

Sedangkan dari nilai $f$ hitung $>$ f tabel yaitu 9,404 > 3,17 dengan demikian maka Ho ditolak dan menrima Ha. Artinya pelatihan dan pemberian insentif berpengaruh signifikan terhadap kinerja karyawan pada tenaga medis. Artinya kelayakan model berpengaruh signifikan antara pelatihan dan pemberian insentif dapat digunakan terhadap kinerja karyawan pada tenaga medis.

\section{KESIMPULAN}

Berdasarkan hasil dan pembahasan yang dilakukan, maka simpulan dalam penelitian ini adalah pelatihan secara parsial berpengaruh signifikan sebesar 254, bahwa peserta selalu bersemangat untuk mengikuti pelatihan. Pemberian insentif secara parsial berpengaruh signifikan sebesar 208, bahwa karyawan memahami kriteria atau persyaratan dalam promosi jabatan dan pelatihan dan pemberian insentif secara simultan berpengaruh signifikan sebesar 220, bahwa karyawan berupaya menjadi individu yang selalu berusaha untuk meningkatkan kualitas kinerja. 
ISSN Cetak : :2087-0434

E-ISSN $\quad: 2599-0810$

\section{DAFTAR REFERENSI}

AA. Anwar Prabu Mangkunegara. 2013. Manajemen Sumber Daya Manusia Perusahaan, Remaja Rosdakarya, Bandung. (Rivai, 2013).

Bastian, Indra. 2001. Akuntansi Sektor Publik di Indonesia. Edisi Pertamta Yogyakarta: BPFE.

Dessler, Gary. 2010. Manajemen Sumber Daya Manusia (edisi kesepuluh). Jakarta Barat: PT Indeks (Rivai dan Sagala, 2011).

Dessler, Gary. 2010. Manajemen Sumber Daya Manusia (edisi kesepuluh). Jakarta Barat: PT Indeks (Widodo, 2015).

Eko, Widodo Suparno. 2015. Manajemen Pengembangan Sumber DayA Manusia. Yogyakarta: PUSTAKA PELAJAR.

Hasibuan, Malayu. 2012. "Manajemen Sumber Daya Manusia". Jakarta: PT Bumi Aksara.

Kasmir. 2016. Analisis Laporan Keuangan. Jakarta: Raja Grafindo Persada.

Muliana, dkk. 2020. Pengantar Manajemen. Yayasan Kita Menulis, Medan

Sugiyono. 2018. Metode Penelitian Kuantitatif. CV Alfabeta. Bandung

Sujarweni, W. 2014. Metodologi Penelitian. Pustaka Baru Pers.Yogyakarta 